Cancanos

\title{
Landscape Change in the Nepal Hills Evidence from Lamjung
}

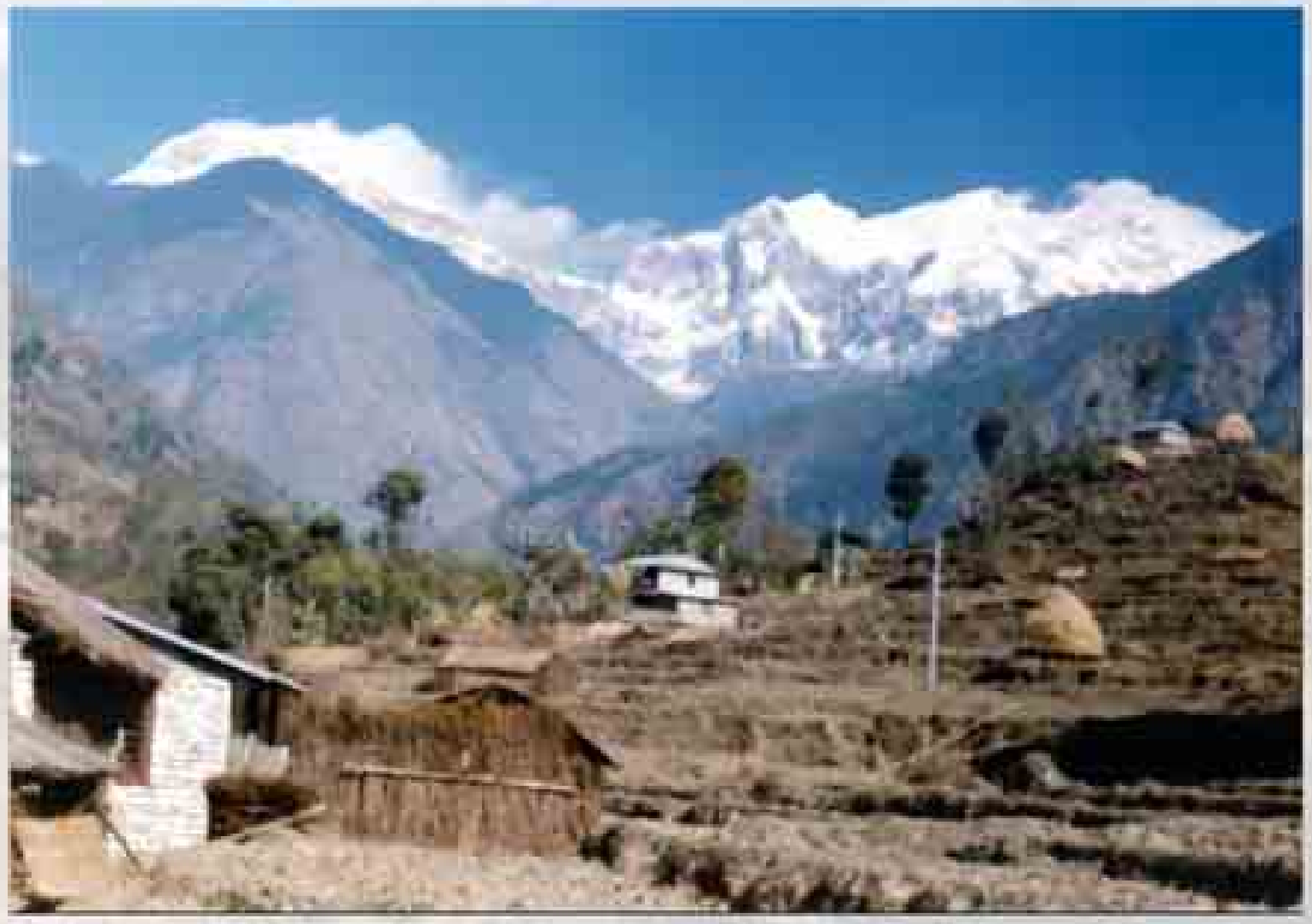

Harka Gurung 


\section{About ICIMOD}

The International Centre for Integrated Mountain Development (ICIMOD) is an independent 'Mountain Learning and Knowledge Centre' serving the eight countries of the Hindu Kush-Himalayas - Afghanistan - Bangladesh

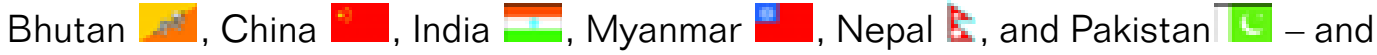
the global mountain community. Founded in 1983, ICIMOD is based in Kathmandu, Nepal, and brings together a partnership of regional member countries, partner institutions, and donors with a commitment for development action to secure a better future for the people and environment of the Hindu Kush-Himalayas. The primary objective of the Centre is to promote the development of an economically and environmentally sound mountain ecosystem and to improve the living standards of mountain populations. 


\title{
Landscape Change in the Nepal Hills Evidence from La m jung
}

\author{
by \\ Harka Gurung
}

International Centre for Integrated Mountain Development (ICIMOD)

Kathmandu, Nepa

August 2004 


\section{Copyright (c) 2004}

International Centre for Integrated Mountain Development (ICIMOD)

All rights reserved

Credits: All the photographs were taken by the author except $11 \mathrm{~A}$ which was taken by D. Messershmidt

Cover: The study area, Taranche $(945 \mathrm{~m})$, is $25 \mathrm{~km}$ south of Himalchuli $(7,893 \mathrm{~m})$ on right. On the left is Ngadichuli $(7,513 \mathrm{~m})$ labeled as Peak 29 by surveyors of 1925-27 and officially named Ngadichuli in 1983. Thulnagi $(3,115 \mathrm{~m})$ in middle distance and Usta ridge on right foreground. December 2001.

\section{ISBN 9291158771}

\section{Published by}

The International Centre for Integrated Mountain Development (ICIMOD)

G.P.O. Box 3226

Kathmandu, Nepal

\section{Editorial Team}

Greta Rana (Editor)

Dharma R. Maharjan (Technical Support and Graphic Design)

Asha K. Thaku (Maps)

\section{Printed and bound in Nepal by}

Hill Side Press $(P)$ Ltd.

Kathmandu, Nepal

The views and interpretations in this paper are those of the author. They are not attributable to the International Centre for Integrated Mountain Development (ICIMOD) and do not imply the expression of any opinion concerning the legal status of any country, territory, city or area of its authorities, or concerning the delimitation of its frontiers or boundaries. 


\title{
Foreword
}

Landscape change in the mountains, including changes in land use, forests and agriculture, architecture, and dwelling areas continues to be the subject of debate and the basis for development investment. Uncertainty over past conditions and rates - and even directions - of some landscape change continue to fuel discussion and drive the need for better documentation and analysis.

Juxtaposing views of the past with the present provides a fascinating method to uncover historical change and speculate on future trends. Repeat landscape photography, especially when done by the same observer, and especially when done by a highly trained and keenly observant professional, provides us with this unique opportunity.

Dr. Harka Gurung, renowned geographer, historian, planner, policy-maker, author, adventurer, and spokesperson for the excluded ethnic groups of the Himalaya, has brought together this extraordinary collection of repeat photographs and observations. A native of the area featured in the documentation, this publication draws on over forty years of his work in the Himalaya.

Photographs and observations such as those presented in this publication give us an objective basis for testing our current theories of land degradation, deforestation, and urbanisation. In this context, lack of change where we expected it can be as revealing as confirmation. While the sample of publications does not claim to be based on anything other than Dr. Gurung's personal and professional interest and opportunity, we believe that it represents a valuable contribution to our understanding of the on-going changes in the Himalayan mountains. ICIMOD is pleased to publish this work.

\author{
J. Gabriel Campbell, Ph.D \\ Director General \\ ICIMOD
}




\section{ACKNOWLEDGEMENTS}

The field research for this study was supported by ICIMOD. I wish to thank Dr. Gabriel Campbell, Director General, and Dr. Binayak Bhadra, Director of Programmes, for their interest in the present study. In Lamjung, Til Bahadur Gurung of Tanklichok and Sant Kumar Bhandari of Taranche assisted in the field work. Narendra Khanal helped in airphoto interpretation and Pawan Ghimire in cartographic work. New ERA staff, Bhoj Kumar Shrestha, Sanu Raja Shakya, and Geeta Shrestha, provided secretarial assistance. I thank them for their cooperation. I also would like to thank Greta Rana for her editorial support, Dharma R. Maharjan for layout design, and Asha K. Thaku for the maps. 


\section{Abstract}

There has been much discussion on the state of the Himalayan environment with a tendency to highlight increasing land degradation. This investigation focussing on a hill area in Lamjung presents a very different ground reality regarding landscape dynamics in central Nepal. The study findings are based on evidence from repeat photographs and field observations extending over four decades. The monograph includes numerous maps and diagrams dealing with geology, geomorphology, climate, vegetation, and land use in the study area. The approach is oriented more towards visual and graphic presentation than verbal description. 


\section{Glossary / Abbreviations}

bari

bazaar

bensi

caste

Central Hills

danda

deorali

ethnic

FINNIDA

gaon

Higher Himalaya

Himal

kharchari

kharga

khet

khola

LRMP

lekh

Lower Himalaya
The term is derived from bar (fence) to refer to the enclosed area of homestead for fruit and vegetable production. It literally means in-field, therefore, it is wrong to equate it with pakho (unirrigated field)

A settlement with commercial services

Valley bottom

Hindu social division according to the ritual status of a person by birth

Subtropical hill zone

Hill range or ridge

Saddle, convergence of two ascents

A social group with a distinct language, religious tradition, culture, and native area

Finnish International Development Agency

Village or rural settlement

Geological term for structural formations over-riding the Main Central Thrust

A mountain range with permanent snow

Tax on alpine pasture

Alpine pasture for summer grazing

Irrigated land with horizontal terraces

River, stream

Land Resource Mapping Project

High ridge with snow in winter

Geological term for structural formations below the Main

Central Thrust and above the Main Boundary Thrust

Main Boundary Thrust Major geological fault or unconformity that separates the SubHimalaya (Siwalik Zone) from the Lower Himalaya

Main Central Thrust

Midland
Major geological fault or unconformity that separates the Lower Himalaya from the Higher Himalaya

This refers to the hill zone of Nepal across the country.

Kawakita" called it 'Lowland' with reference to its low elevation relative to the main Himalaya and Mahabharat Lekh. Hagen ${ }^{* * *}$ referred to it as 'Midland', and this definition has been adopted by many others. It can be equated with the pahar (hill) zone. 
muri

Ngadi

pahar

pahara

pakho

ropani

sinyala

Sardar
Volumetric measurement for grain, equivalent to 2.40 bushels The name of a river that has been spelled diversely. The quarter inch (1:253,000) map of the Survey of India (1925-27) rendered it as 'Musi' (Figure 13). The one inch map (1:63,360) of the Survey of India and that of the Land Resource Mapping Project render it 'Nyadi'. The FINNIDA map $(1: 50,000)$ spells it as 'Nadi' (Figure 5). The name is derived from a combination of Nga (ritual hand-drum) and 'ti' (broken) to mean 'broken drum' according to a Gurung legend.

Hill with no snowfall

South-facing or sunny aspect (comparable to the the French term 'adret' and the German 'Sonnenseite')

Unirrigated or rain-fed field with outward sloping terraces

Area measurement equivalent to 5,476 square feet, 1 hectare $=19.7$ ropani

North-facing or shady aspect (comparable to the French term 'ubac' and the German 'shattenseite')

Originally a term for an army commander, later it became the term for the highest ranked official in the Nepalese bureaucracy.

Note: In general throughout this text the Sanskrit term Himalaya, normally used specifically geographical/ geological area, rather than the English language derivative, Himalayas, is used. 


\section{Editorial note}

Page numbers for references cited are given in the reference list, not in the text. An exception is made in the case of op. cit. citations. 


\section{Contents}

Foreword

Acknowledgement

Abstract

Glossary/Abbreviations

Editorial note

Chapter 1: INTRODUCTION

1. The Study Area

2. Methodology and Data 5

Chapter 2: GEOMORPHIC EXPRESSION 11

1. Geology 11

2. Landform 13

3. Landslides (1958-1996) 19

Chapter 3: LAND USE 27

1. Climate and Vegetation 27

2. Land-use Change (1958-1996) 30

Chapter 4: VISUAL EVIDENCE 43

$\begin{array}{ll}\text { Chapter 5: DISCUSSION } & 47\end{array}$

Chapter 6: EXPLANATION 53

$\begin{array}{ll}\text { REFERENCES } & 77\end{array}$

$\begin{array}{lr}\text { ANNEXES } & 81\end{array}$ 


\section{List of Tables}

1. Elevation zones, Lamjung 2

2. Taranche terraces 19

3. Temperature at two locations 28

4. Rainfall at two locations 29

5. Land-use change, Marsyangdi-Ngadi confluence 36

6. Land-use change, Taranche 37

7. Outmigration from the Central Hill 55

\section{List of Figures}

1. Lamjung district: study area 3

2. Marsyangdi-Ngadi confluence 4

3. Taranche aerial photographs 1958 and 1996

4. River terraces, Taranche $\quad 7$

5. Topographic map with photo index 8

6. Geological map 12

7. Land systems map 14

8. Taranche area from the north, (A ) October 1962 and (B) March $2002 \quad 16$

9. Taranche area from the south, (A ) October 1962 and (B) January 2002

10. River terraces, Marsyangdi-Ngadi 18

11. Taranche from the west, (A) 1971/72 (B) March 2002

12. Tagaring from the south-east, (A) October 1962 and (B) March 2002

13. Tagaring landslide from the east, (A) October 1962 and (B) March 2002) 23

14. Landslides, Marsyangdi-Ngadi, 1958

15. Landslides, Marsyangdi-Ngadi, 1996

16. Temperature at two locations 28

17. Rainfall at two locations 29

18. Ecological map $\quad 31$

19. Land capability map 32

20. Land use, Marsyangdi-Ngadi, 1958

21. Land use Marsyangdi Ngadi, 1996

22. Abandoned fields, January 2002

23. Land use, Taranche, 1958

24. Land use, Taranche, 1996

25. Bimire from the south, (A) November 1962 and (B) January 2002

26. Ngadi Bazaar and Tanklichowk, January 2001

27. Chiyabari landslide, (A) November 1988 and (B) January 2002

28. Bimire, (A) November 1988 and (B) March $2001 \quad 45$

29. Naiche from the air, October 1989

30. Ngadi Valley from the north, October 1962

31. Khudi Bazaar, (A) October 1962 and (B) December 2001

32. Ngadi Khola, (A) October 1962 and (B) January 200249

33. Marsyangdi-Khudi confluence from the east, (A) October 1962 and
(B) March 2002

34. Marsyangdi-Khudi confluence from the south, (A) October 1962 and

(B) February $2000 \quad 58$

35. Bhulbhule, (A) October 1962 and (B) March $2002 \quad 59$ 
36. Sinyale Chhahara, (A) November 1962 and (B) December $2002 \quad 60$

37. Nandeswanra, (A) November 1962 and (B) December 2002

38. Opposite Sirubari, (A) October 1962 and (B) January 2002

39. South view from Bimire, (A) October 1962 and (B) March 2002

40. Tanklichok from the east, (A) October 1962 and (B) January 2002

41. North view from Tanklichok, (A) October 1962 and (B) January 2002

42. Thulibensi from Usta, (A) October 1962 and (B) January 2002

43. Ngadi Valley from the south, (A) November 1962 and (B) January 2002

44. Naiche from the south-east, (A) October 1962 and (B) January 2002

45. Usta from the north, (A) November 1962 and (B) March 2001

46. Naiche from the west, (A) October 1962 and (B) January 2002

47. Naiche from the west, (A) October 1962 and (B) January 2002

48. Naiche fields, (A) November 1962 and (B) January 2002

49. Naiche fields, (A) October 1962 and (B) January 2002

50. Naiche shrine, (A) November 1962 and (B) January 2002

51. Tarachok from the north, (A) October 1962 and (B) March 2002

\section{List of Annexes}

A. Profile of Settlements, $2001 \quad 81$

B. Chronology of Events $\quad 82$

C. Taranche Land Record 83

D. Lamjung Population Trend 84 